\title{
Response Surface Optimization and Impact of Immobilized Enzymes Naringianse and Tannase on the Quality Parameters of Citrus maxima Juice
}

\author{
Sanjay Kumar ${ }^{1}, * \mathbb{( D )}$, Vijay Kumar ${ }^{2}$ (i) , Pankaj Gautam ${ }^{1}$ \\ 1 Department of Life Sciences (Food Technology), Graphic Era Deemed to Be University, Dehradun \\ 2 Himalayan School of Biosciences, Swami Ram Himalayan University, Jolly Grant, Dehradun \\ * Correspondence: sanjaykumar@geu.ac.in;
}

Scopus Author ID 57208487301

Received: 29.10.2020; Revised: 2.12.2020; Accepted: 8.12.2020; Published: 12.12.2020

\begin{abstract}
Pomelo has been reported as a rich source of flavanone glycoside with antioxidants and exhibits favorable health effects such as antimicrobial, anti-inflammatory, antiatherogenic, antitumor, and anti-clotting activity. Despite all the beneficial health impacts of Citrus maxima, it still has lower commercial value because of its juice's bitterness due to the presence of naringin and tannic acid. Therefore, an attempt has been made for the cost-effective and economic debittering process using naringinase and tannase enzymes. The 17 experiments were planned according to RSM, BBD to analyze the effect of independent variables with three levels of each, i.e., Enzyme ratio ((Naringinase: tannase) $(100: 0,50: 50,0: 100))$, incubation temperature $\left(30^{\circ} \mathrm{C}, 40^{\circ} \mathrm{C}, 50^{\circ} \mathrm{C}\right)$ and incubation time $(2,3,4 \mathrm{hrs})$ on physicochemical quality of Citrus maxima Juice. The study's result indicated that independent variables affected the responses ( $\mathrm{pH}$, TSS, TA, Naringin content, Tannin content, TPC, and Vitamin C content). Optimization was done using Design Expert 10.0.1 software to debitter and clarify citrus maxima juice by immobilized enzymes. The optimum values were found to be $54.55,50^{\circ} \mathrm{C}$, and $4 \mathrm{hrs}$. The values for $\mathrm{pH}$, TSS, TA, Naringin content, Tannin content, TPC and Vitamin C content were found to be 3.17, $6.256{ }^{\circ}$ Brix, $0.885 \%$ citric acid , $220.549 \mu \mathrm{g} / \mathrm{ml}, 0.311 \mathrm{mg} / \mathrm{ml}, 1256.721 \mathrm{mg} \mathrm{GAE} / \mathrm{L}, 30.309 \mathrm{mg} / 100 \mathrm{ml}$ respectively. From the study, it could be concluded that the maximum debittering and clarification of citrus maxima juice could be done under processing conditions, i.e., enzyme ratio 50:50, incubation temperature $50^{\circ} \mathrm{C}$ and incubation time $4 \mathrm{hrs}$.
\end{abstract}

Keywords: Citrus maxima; naringinase; tannase; total phenolic content; tannin content; naringin content.

(c) 2020 by the authors. This article is an open-access article distributed under the terms and conditions of the Creative
Commons Attribution (CC BY) license (https://creativecommons.org/licenses/by/4.0/).

\section{Introduction}

Citrus maxima (or Citrus grandis), commonly known as Chakotra, pomelo, and jabong [1] has been reported as a rich source of naringin, a bitter flavored, flavanone glycoside with antioxidant [2], and exhibit favorable health effects such as antimicrobial, anti-inflammatory, antiatherogenic, antitumor, and anti-clotting activity [3-5]. Citrus maxima juice contains antinutrients like phytic acid, tannin, and oxalate [6]. Bitter compounds are present in a different part of a single fruit [7]. Naringin is the source of undesirable bitterness [8], especially in the citrus fruit juice industry; therefore, it must be removed or reduced from processed products [9-11]. Also, upon storage of the juices, due to tannin content, certain factors such as sedimentation, haziness, color, astringency [12-13], and bitterness get increased [14-15]. These problems can be solved using the enzymes naringinase produced by different microbial strains 
[16] and tannase produced by several microbial strains [17]. Naringinase hydrolyzes naringin to naringenin, a non-bitter derivative, which cannot be reconverted to naringin [18-19] and glucose [20-21], resulting in an improvement in the taste of citrus juice [22]. Besides, naringinase plays an important role in modifying flavonoids to yield highly bioactive compounds [23-24]. Similarly, tannin acyl hydrolase, i.e., tannase enzyme (EC 3.1.1.20), has been used to produce gallic acid and glucose from tannins [25]. This enzyme has found its role in various applications world-wide, especially in pharmaceuticals, tannery, beverage, and alcohol industries for clarification purposes [26-27].

Despite all the beneficial health impacts of Citrus maxima, it still has lower commercial value because of its juice's bitterness. Therefore, a cost-effective and economic debittering process could be achieved if naringinase and tannase produced industrially using microorganisms [28]. Hence, this study's objective was debittering and clarifying Citrus maxima juice by immobilized enzyme naringinase and tannase produced from Aspergillus $s p$. isolate SK01 isolated from rotten Citrus maxima.

\section{Materials and Methods}

\subsection{Materials.}

Citrus maxima of sound quality were brought from Dehradun's local market and washed properly 2-3 times with tap water and then with distilled water to remove dirt. The flavedo and albedo were peeled and separated from the pulp. The pulp was blended and filtered through a muslin cloth to obtain a clear juice and stored in a refrigerator at $4{ }^{\circ} \mathrm{C}$ for further analysis. All the chemicals of the analytical grade used in this study were purchased from Hi-Media, Mumbai, India.

\subsection{Production of enzymes.}

Enzymes naringinase and tannase were produced through submerged fermentation by the method of [29-30] and [31] respectively from Aspergillus sp. isolate SK01 and partially purified by ammonium sulfate $(80 \%)$ ppt method. Naringinase activity was assayed with respect to naringin using Davis's method [32] with little modification. Tannase activity was determined calorimetrically using the method of Mondal [33]. The activity of partially purified crude enzymes naringinase and tannase was $1.63 \mathrm{IU} / \mathrm{ml}$ and $1.18 \mathrm{IU} / \mathrm{ml}$, respectively.

\subsection{Immobilization of naringinase.}

Immobilization of Naringinase was done by [34] with some modifications. Briefly, a 5 $\mathrm{ml}$ suspension containing crude naringinase at a concentration of $1 \mathrm{~g} / 1$ and $3 \%$ sodium alginate was extruded into a $0.2 \mathrm{M} \mathrm{CaCl}_{2}$ solution at a temperature of $4^{\circ} \mathrm{C}$ to form the gel beads. After $4 \mathrm{~h}$ the beads were washed 2-3 times with $0.1 \mathrm{M}$ sodium acetate buffer, $\mathrm{pH} 4.0$, and used for naringinase assay.

\subsection{Immobilization of tannase.}

Tannase was done by [35] with some modifications. Briefly, a $5 \mathrm{ml}$ suspension containing tannase at a concentration of $1 \mathrm{~g} / 1$ and $3 \%$ sodium alginate was extruded into a 0.2 $\mathrm{M} \mathrm{CaCl}_{2}$ solution at a temperature of $4^{\circ} \mathrm{C}$ to form the gel beads. After $4 \mathrm{~h}$ the beads were washed 2-3 times with water and kept at $4^{\circ} \mathrm{C}$. 


\subsection{Identification and selection of the most important variables.}

Several experiments were carried out to standardize the parameters for debittering and clarification of Citrus maxima juice by immobilized enzyme naringinase and tannase produced from Aspergillus sp. isolate SK01 isolated from rotten Citrus maxima.

Enzyme ratios were selected to show the effect of naringinase and tannase individually or in a combination of both enzymes on debittering and clarification characteristics of Citrus maxima juice as an individual or in a combination of both. The enzyme ratios range (100:0, $50: 50,0: 100)$ were selected. Based on preliminary experiments, incubation temperature $\left(30^{\circ} \mathrm{C}\right.$, $\left.40^{\circ} \mathrm{C}, 50^{\circ} \mathrm{C}\right)$ and incubation time $(2,3,4 \mathrm{hrs})$ were selected as variables.

\subsection{Physiochemical analysis.}

$\mathrm{pH}$ was measured by handy $\mathrm{pH}$ meter (Eutech), TSS was measured by using a hand refractometer (ERMA). Titrable acidity was measured by [36], Vitamin C (mg/100ml) was measured by the method of [37-38]. Total Phenolic Content (mg GAE/L) was measured as described[39]. Tannin content $(\mathrm{mg} / \mathrm{ml})$ and naringin content $(\mu \mathrm{g} / \mathrm{ml})$ in Citrus maxima juice were determined by the method of [40-41], respectively.

\subsection{Statistical analysis.}

Design-Expert 10.0.1 was used for data analysis and process optimization. To evaluate the effect of process parameters, i.e., enzyme ratios (naringinase: tannase), incubation temperature $\left({ }^{\circ} \mathrm{C}\right.$ ) and incubation time (hrs.) on the responses, i.e., $\mathrm{pH}$, TSS, titrable acidity, naringin content, tannin content, TPC and vitamin $\mathrm{C}$ content a second-order response function was implemented for three independent variables having following general form Equation (1) [42-43].

$$
Y=\beta_{0}+\sum_{i=1}^{3} \beta_{i} X_{i}+\sum_{i=1}^{2} \sum_{j=i+1}^{3} \beta_{i j} X_{i} X_{j}+\sum_{i=1}^{3} \beta_{i i} X_{i}^{2}
$$

Where,

$\mathrm{Y}=$ Response

$\beta 0, \beta \mathrm{ii}, \beta \mathrm{ij}=$ Coefficients

$\mathrm{Xi}$ and $\mathrm{Xj}=$ Independent Variables

ANOVA was used for determining the statistical significance of the independent parameters and their relative interactions. The model's adequacy was explained in terms of $\mathrm{R}^{2}$ (coefficient of determination), F-value (Fisher's value), and LOF (lack-of-fit)

\section{Results and Discussion}

A total of 17 experiments were designed by using the Box-Benkhen design of RSM. These runs were performed to see the effect of the selected process parameters- enzyme ratio, temperature \& time on the said responses, i.e., naringin content, tannin content, TPC, and vitamin $\mathrm{C}$. The results were statistically analyzed for being either significant or non-significant. The results of the experiment are given in Table 1. Table 2 and Table 3 show the ANOVA and regression analysis performed to check the model's adequacy. Constraints for optimization for independent variables/ dependent variables are given in Table 5. 


\subsection{Effect on $\mathrm{pH}$}

Full second order equation to show the effect of $\mathrm{X}_{1}, \mathrm{X}_{2}$ and $\mathrm{X}_{3}$ on $\mathrm{pH}$ could be explained by the equation given below.

$$
\mathrm{pH}=3.28+0.0375 \mathrm{X}_{1}+0.0375 \mathrm{X}_{2}-0.050 \mathrm{X}_{3}-0.075 \mathrm{X}_{1} \mathrm{X}_{2}-0.15 \mathrm{X}_{1} \mathrm{X}_{3}+1.08 \times 10^{-}
$$

${ }^{16} \mathrm{X}_{2} \mathrm{X}_{3}-0.10250 \mathrm{X}_{1}{ }^{2}-0.0525 \mathrm{X}_{2}^{2}-0.0275 \mathrm{X}_{3}{ }^{2}$

Where,

$\mathrm{X}_{1}, \mathrm{X}_{2}$ and $\mathrm{X}_{3}$ are Enzyme ratios (naringinase: tannase), temperature, and time respectively.

The total effect of individual parameters on $\mathrm{pH}$ at linear, quadratic, and interactive levels is reported in table 3. The F value (16.22) for the model was significant at $1 \%(p<0.01)$ level of. Correlation coefficient $\mathrm{R}^{2}$ measures the generosity of fit of the model. The $\mathrm{R}^{2}$ value for $\mathrm{pH}$ was $95.42 \%$, which means that the model could account for $95.42 \%$ of the data. The model does not elucidate the variation of $4.58 \%$. The $\mathrm{R}^{2}$ value higher than $90 \%$ showed that the regression model explained the reaction well. The Pred R-Squared of $77.12 \%$ was in equitable agreement with the Adj R-Squared of $89.54 \%$. Lack of fit, i.e., LOF was insignificant; hence, the second-order model was acceptable in describing $\mathrm{pH}$. The $\mathrm{pH}$ value for debittered juice was varied from 3.0 to 3.4 (Table 3 ). The highest $\mathrm{pH}$ score was found maximum (3.4) at the level of $\mathrm{X}_{1}(0: 100), \mathrm{X}_{2}\left(40^{\circ} \mathrm{C}\right)$, and $\mathrm{X}_{3}(2 \mathrm{hrs})$.

The $\mathrm{pH}$ value for debittered juice was varied from 3.0 to 3.4 (Table 3 ). The highest $\mathrm{pH}$ score was found maximum (3.4) at the level of $\mathrm{X}_{1}(0: 100), \mathrm{X}_{2}\left(40^{\circ} \mathrm{C}\right)$, and $\mathrm{X}_{3}(2 \mathrm{hrs})$.

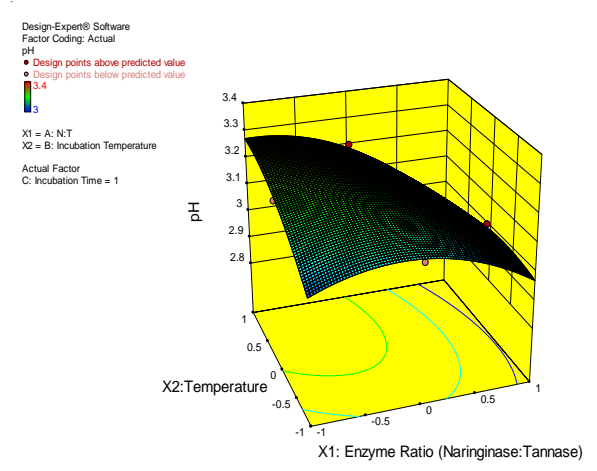

(i)

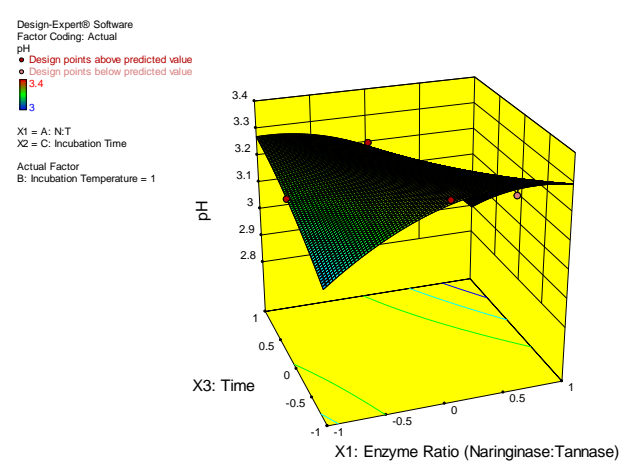

(ii)

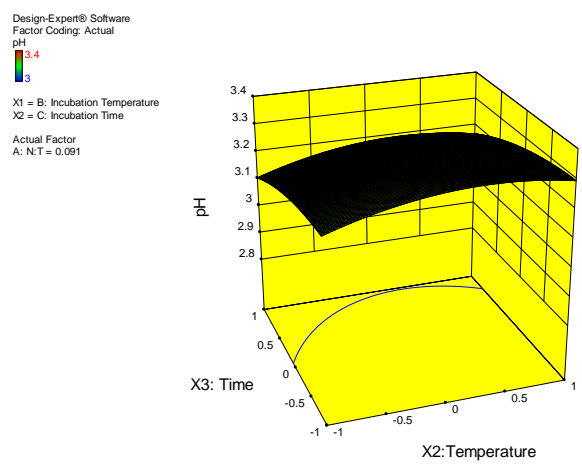

(iii)

Figure 1. 3D Response surface showing interaction effect of variables on $\mathrm{pH}$ of debittered Citrus maxima juice i) temperature and enzyme ratio ii) time and enzyme ratio and iii) time and temperature.

The 3D response surface curve for $\mathrm{pH}$ was presented in Figure 1. (i, ii \& iii). The values presented in Table 3 show that there were no significant changes in the $\mathrm{pH}$ of the debittered juice. Figure1 (i) shows that as temperature increase $\left(30^{\circ} \mathrm{C}\right.$ to $\left.50^{\circ} \mathrm{C}\right), \mathrm{pH}$ was increased in the presence of enzyme ratio. 


\begin{tabular}{|c|c|c|c|c|c|c|}
\hline \multirow[t]{2}{*}{ Expt. No. } & \multicolumn{3}{|c|}{ Coded Levels } & \multicolumn{3}{|c|}{ Real Levels } \\
\hline & $\mathrm{X}_{1}$ & $\mathrm{X}_{2}$ & $\mathrm{X}_{3}$ & $\begin{array}{l}\text { Enzymes Blend ratios } \\
\text { (Naringinase: } \\
\text { Tannase) }\end{array}$ & Temperature $\left({ }^{\circ} \mathrm{C}\right)$ & Time (hrs) \\
\hline 1 & -1 & -1 & 0 & $100: 0$ & 30 & 3 \\
\hline 2 & 1 & -1 & 0 & $0: 100$ & 30 & 3 \\
\hline 3 & -1 & 1 & 0 & 100:0 & 50 & 3 \\
\hline 4 & 1 & 1 & 0 & $0: 100$ & 50 & 3 \\
\hline 5 & -1 & 0 & -1 & 100:0 & 40 & 2 \\
\hline 6 & 1 & 0 & -1 & $0: 100$ & 40 & 2 \\
\hline 7 & -1 & 0 & 1 & $100: 0$ & 40 & 4 \\
\hline 8 & 1 & 0 & 1 & $0: 100$ & 40 & 4 \\
\hline 9 & 0 & -1 & -1 & $50: 50$ & 30 & 2 \\
\hline 10 & 0 & 1 & -1 & $50: 50$ & 50 & 2 \\
\hline 11 & 0 & -1 & 1 & $50: 50$ & 30 & 4 \\
\hline 12 & 0 & 1 & 1 & $50: 50$ & 50 & 4 \\
\hline 13 & 0 & 0 & 0 & $50: 50$ & 40 & 3 \\
\hline 14 & 0 & 0 & 0 & $50: 50$ & 40 & 3 \\
\hline 15 & 0 & 0 & 0 & $50: 50$ & 40 & 3 \\
\hline 16 & 0 & 0 & 0 & 50:50 & 40 & 3 \\
\hline 17 & 0 & 0 & 0 & $50: 50$ & 40 & 3 \\
\hline
\end{tabular}

Figure 1 (ii) showed that the $\mathrm{pH}$ increase as time increases (2-4 hrs) with different enzyme ratio levels. Figure 1. (iii) depicted that the $\mathrm{pH}$ increased along with an increasing level of time and temperature. A similar finding was observed by[44] in the case of the enzymatic treatment of pomegranate juice.

From table 6 of coefficient, it was observed that $\mathrm{X}_{1}$ (enzyme ratio) and $\mathrm{X}_{2}$ (temperature) had a positive effect on $\mathrm{pH}$ at $5 \%$ level, i.e., $\mathrm{p}<0.05$ of significance at linear level, while $\mathrm{X}_{3}$ (Time) had a negative effect at $1 \%$ level, i.e., $\mathrm{p}<0.01$ of significance. Interactive effect of $\mathrm{X}_{2}$ (temperature), $\mathrm{X}_{3}$ (time) had significant positive effect at $10 \%$ level i.e. $\mathrm{p}<0.1$ of significance while $\mathrm{X}_{1}$ (enzyme ratio), $\mathrm{X}_{2}$ (temperature) and $\mathrm{X}_{1}$ (enzyme ratio), $\mathrm{X}_{3}$ (time) had negative effect at $1 \%$ level i.e. $\mathrm{p}<0.01$ of significance. Quadratic effect of $\mathrm{X}_{1}$ (enzyme ratio), $\mathrm{X}_{2}$ (temperature) and $\mathrm{X}_{3}$ (time) was negative at $1 \%$ i.e. $\mathrm{p}<0.01,5 \%$ level i.e. $\mathrm{p}<0.05$ and more than $10 \%$ level i.e. $\mathrm{p}<0.1$ of significance respectively.

Table 2. Independent variables (coded and actual value).

\begin{tabular}{l|c|c|c|c}
\multicolumn{2}{c}{ Independent variables } & \multicolumn{3}{c}{ Coded Levels } \\
\hline \multirow{2}{*}{ Name } & \multirow{2}{*}{ Code } & -1 & \multicolumn{3}{c}{ Actual Levels } \\
\cline { 3 - 5 } & $\mathrm{X}_{1}$ & $100: 0$ & $50: 50$ & $0: 100$ \\
\hline $\begin{array}{l}\text { Enzymes Blend ratios } \\
\text { (Naringinase: Tannase) }\end{array}$ & $\mathrm{X}_{2}$ & 30 & 40 & 50 \\
\hline Temperature $\left({ }^{\circ} \mathrm{C}\right)$ & $\mathrm{X}_{3}$ & 2 & 3 & 4
\end{tabular}

\subsection{Effect on TSS.}

The effect of $X_{1}, X_{2}$, and $X_{3}$ on TSS could be explained by the equation given below.

$\mathrm{TSS}=7.26-1.1625 \mathrm{X}_{1}-0.0375 \mathrm{X}_{2}-0.0250 \mathrm{X}_{3}+0.075 \mathrm{X}_{1} \mathrm{X}_{2}+0.150 \mathrm{X}_{1} \mathrm{X}_{3}-0.200$ $\mathrm{X}_{2} \mathrm{X}_{3}+0.482 \mathrm{X}_{1}^{2}-0.217 \mathrm{X}_{2}^{2}-0.44250 \mathrm{X}_{3}^{2}$ 
https://doi.org/10.33263/BRIAC114.1153511552

Table 3. Experimental data for debittering and clarification of pomelo juice by using immobilized enzyme naringinase and tannase and combination of both.

\begin{tabular}{|c|c|c|c|c|c|c|c|c|c|c|}
\hline \multicolumn{4}{|c|}{ Variables } & \multicolumn{7}{|c|}{ Responses } \\
\hline Exp. No. & $\begin{array}{c}\text { Enzymes Blend ratios } \\
\text { (Naringinase: Tannase) }\end{array}$ & Temp. $\left({ }^{\circ} \mathrm{C}\right)$ & Time (hrs) & pH & $\begin{array}{c}\text { TSS } \\
\left({ }^{\circ} \text { Brix }\right) \\
\end{array}$ & $\begin{array}{c}\text { TA } \\
(\% \text { citric acid })\end{array}$ & $\begin{array}{c}\text { Naringin content } \\
(\mu \mathrm{g} / \mathrm{ml})\end{array}$ & $\begin{array}{c}\text { Tannin content } \\
(\mathrm{mg} / \mathrm{ml})\end{array}$ & $\begin{array}{c}\text { TPC } \\
\text { mgGAE/L }\end{array}$ & $\begin{array}{c}\text { Vitamin C content } \\
(\mathrm{mg} / 100 \mathrm{ml})\end{array}$ \\
\hline 1 & $100: 0$ & 30 & 3 & $3.0^{*}$ & $8.8^{* *}$ & 0.98 & 505.8 & $0.68^{* *}$ & 1819.8 & $58.2^{* *}$ \\
\hline 2 & $0: 100$ & 30 & 3 & 3.2 & 6.3 & 0.97 & $686.5^{* *}$ & 0.63 & 1632.8 & 55.2 \\
\hline 3 & 100:0 & 50 & 3 & 3.2 & 8.6 & $0.99^{* *}$ & 213.8 & 0.60 & $1822.8^{* *}$ & 52.2 \\
\hline 4 & $0: 100$ & 50 & 3 & 3.1 & 6.4 & 0.92 & 544.3 & 0.41 & 1518.8 & 47.6 \\
\hline 5 & 100:0 & 40 & 2 & $3.0^{*}$ & 8.7 & 0.85 & 419.5 & 0.65 & 1660.7 & 53.4 \\
\hline 6 & $0: 100$ & 40 & 2 & $3.4^{* *}$ & $6.1^{*}$ & $0.84^{*}$ & 659.8 & 0.62 & 1177.4 & 53.1 \\
\hline 7 & 100:0 & 40 & 4 & 3.2 & 8.2 & 0.86 & 414.2 & $0.68^{* *}$ & 1695.7 & 54.4 \\
\hline 8 & $0: 100$ & 40 & 4 & $3.0^{*}$ & 6.2 & 0.85 & 612.4 & 0.55 & 1362.7 & 45.4 \\
\hline 9 & $50: 50$ & 30 & 2 & 3.2 & 6.4 & 0.89 & 415.5 & 0.52 & 1218.6 & 44.5 \\
\hline 10 & $50: 50$ & 50 & 2 & 3.3 & 6.7 & 0.88 & 226.5 & 0.39 & 1230.3 & 37.5 \\
\hline 11 & $50: 50$ & 30 & 4 & 3.1 & 6.9 & 0.91 & 354.3 & 0.55 & 1389.6 & 38.8 \\
\hline 12 & 50:50 & 50 & 4 & 3.2 & 6.4 & 0.89 & $216.9^{*}$ & $0.31^{*}$ & 1265.7 & 29.3 \\
\hline 13 & $50: 50$ & 40 & 3 & 3.3 & 7.3 & 0.97 & 365.5 & 0.50 & 1125.3 & 26.8 \\
\hline 14 & $50: 50$ & 40 & 3 & 3.3 & 7.3 & 0.95 & 304.2 & 0.49 & $1048.0^{*}$ & 24.8 \\
\hline 15 & 50:50 & 40 & 3 & 3.3 & 7.3 & 0.96 & 305.3 & 0.50 & 1125.3 & 24.8 \\
\hline 16 & 50:50 & 40 & 3 & 3.3 & 7.2 & 0.95 & 305.5 & 0.50 & 1124.3 & $24.5^{*}$ \\
\hline 17 & $50: 50$ & 40 & 3 & 3.2 & 7.2 & 0.97 & 363.5 & 0.48 & 1125.3 & 26.8 \\
\hline
\end{tabular}

* Minimum value

**Maximum value

Table 4. ANOVA for different responses.

\begin{tabular}{|c|c|c|c|c|c|c|c|c|c|c|c|c|c|c|c|}
\hline \multirow[t]{2}{*}{ Source } & \multirow[t]{2}{*}{$\begin{array}{c}\text { Degree } \\
\text { of } \\
\text { freedom }\end{array}$} & \multicolumn{2}{|c|}{ pH } & \multicolumn{2}{|c|}{$\begin{array}{c}\text { TSS } \\
\left({ }^{(} \text {Brix }\right)\end{array}$} & \multicolumn{2}{|c|}{$\begin{array}{c}\text { TA } \\
\text { (\% citric acid) }\end{array}$} & \multicolumn{2}{|c|}{$\begin{array}{l}\text { Naringin content } \\
(\mu \mathrm{g} / \mathrm{ml})\end{array}$} & \multicolumn{2}{|c|}{$\begin{array}{l}\text { Tannin content } \\
(\mathrm{mg} / \mathrm{ml})\end{array}$} & \multicolumn{2}{|c|}{$\begin{array}{c}\text { TPC } \\
(\text { mgGAE/L) }\end{array}$} & \multicolumn{2}{|c|}{$\begin{array}{c}\text { Vitamin } C \\
\text { content } \\
(\mathrm{mg} / 100 \mathrm{ml})\end{array}$} \\
\hline & & F value & $\begin{array}{l}\text { P Value } \\
\text { Prob }>\mathbf{F}\end{array}$ & F value & $\begin{array}{ll}\text { P } \quad \text { Value } \\
\text { Prob }>\text { F }\end{array}$ & $\begin{array}{l}\text { F } \\
\text { value }\end{array}$ & $\begin{array}{ll}\mathbf{P} \quad \text { Value } \\
\text { Prob }>\mathbf{F}\end{array}$ & $\begin{array}{l}\text { F } \\
\text { value }\end{array}$ & $\begin{array}{l}\text { P Value } \\
\text { Prob }>\mathbf{F}\end{array}$ & F value & $\begin{array}{l}\text { P } \quad \text { Value } \\
\text { Prob>F }\end{array}$ & F value & $\begin{array}{l}\text { P Value } \\
\text { Prob }>\mathbf{F}\end{array}$ & F value & $\begin{array}{l}\text { P Value } \\
\text { Prob }>\mathbf{F}\end{array}$ \\
\hline Model & 9 & 16.22 & 0.0007 & 170.08 & $<0.0001$ & 37.17 & $<0.0001$ & 42.54 & $<0.0001$ & 76.04 & $<0.0001$ & 47.76 & $<0.0001$ & 147.92 & $<0.0001$ \\
\hline$X_{1}$ & 1 & 7.50 & 0.0290 & 1271.91 & $<0.0001$ & 10.00 & 0.0159 & 123.20 & $<0.0001$ & 80.23 & $<0.0001$ & 83.07 & $<0.0001$ & 18.87 & 0.0034 \\
\hline$X_{2}$ & 1 & 7.50 & 0.0290 & 1.32 & 0.2877 & 4.90 & 0.0625 & 79.03 & $<0.0001$ & 225.09 & $<0.0001$ & 2.42 & 0.1636 & 59.86 & 0.0001 \\
\hline $\mathbf{X}_{3}$ & 1 & 13.33 & 0.0082 & 0.59 & 0.4682 & 2.50 & 0.1579 & 2.08 & 0.1921 & 4.06 & 0.0837 & 8.85 & 0.0207 & 28.04 & 0.0011 \\
\hline $\mathbf{X}_{1} \mathbf{X}_{2}$ & 1 & 15.00 & 0.0061 & 2.65 & 0.1478 & 7.20 & 0.0314 & 6.13 & 0.0425 & 19.66 & 0.0030 & 1.33 & 0.2865 & 0.34 & 0.5791 \\
\hline $\mathbf{X}_{1} \mathbf{X}_{3}$ & 1 & 60.00 & 0.0001 & 10.59 & 0.0140 & 0.000 & 1.0000 & 0.48 & 0.5090 & 10.03 & 0.0158 & 2.20 & 0.1819 & 10.00 & 0.0159 \\
\hline $\mathbf{X}_{2} \mathbf{X}_{3}$ & 1 & 0.000 & 1.0000 & 18.82 & 0.0034 & 0.20 & 0.6682 & 0.73 & 0.4219 & 12.13 & 0.0102 & 1.79 & 0.2230 & 0.83 & 0.3937 \\
\hline $\mathrm{X}_{1}^{2}$ & 1 & 29.49 & 0.0010 & 115.32 & $<0.0001$ & 11.84 & 0.0108 & 167.84 & $<0.0001$ & 304.42 & $<0.0001$ & 253.51 & $<0.0001$ & 972.52 & $<0.0001$ \\
\hline $\mathbf{X}_{2}^{2}$ & 1 & 7.74 & 0.0272 & 23.43 & 0.0019 & 19.00 & 0.0033 & 4.77 & 0.0653 & 39.32 & 0.0004 & 62.52 & $<0.0001$ & 104.57 & $<0.0001$ \\
\hline $\mathrm{X}_{3}^{2}$ & 1 & 2.12 & 0.1885 & 96.99 & $<0.0001$ & 280.47 & $<0.0001$ & 0.21 & 0.6638 & 0.18 & 0.6854 & 1.38 & 0.2789 & 58.56 & 0.0001 \\
\hline Lack of fit & 3 & 0.42 & 0.7510 & 5.28 & 0.0709 & 1.58 & 0.3258 & 0.68 & 0.6108 & 5.94 & 0.0591 & 3.72 & 0.1184 & 1.97 & 0.2612 \\
\hline Std. Dev. & & 0.039 & & 0.092 & & 0.011 & & 30.25 & & 0.016 & & 50.71 & & 1.38 & \\
\hline Mean & & 3.19 & & 7.18 & & 0.92 & & 406.68 & & 0.53 & & $\begin{array}{l}1373.1 \\
2\end{array}$ & & 41.02 & \\
\hline $\mathbf{R}^{2}$ & & 0.9542 & & 0.9954 & & 0.9795 & & 0.9820 & & 0.9899 & & 0.9840 & & 0.9948 & \\
\hline
\end{tabular}

https://biointerfaceresearch.com/ 
https://doi.org/10.33263/BRIAC114.1153511552

\begin{tabular}{|c|c|c|c|c|c|c|c|}
\hline $\mathbf{R}_{\mathrm{adj}}^{2}$ & 0.8954 & 0.9896 & 0.9532 & 0.9590 & 0.9769 & 0.9634 & 0.9880 \\
\hline Pred R-Squared & 0.7712 & 0.9404 & 0.8074 & 0.8848 & 0.8648 & 0.8047 & 0.9468 \\
\hline Adeq Precision & 13.887 & 39.421 & 17.784 & 20.062 & 30.451 & 19.377 & 31.503 \\
\hline $\mathrm{CV}(\%)$ & 1.21 & 1.28 & 1.22 & 7.44 & 2.96 & 3.69 & 3.55 \\
\hline Model & $\mathrm{Sig}$ & Sig & Sig & $\mathrm{Sig}$ & $\mathrm{Sig}$ & Sig & Sig \\
\hline Lack of Fit & $\begin{array}{l}\text { NOT } \\
\text { Sig }\end{array}$ & $\begin{array}{l}\text { NOT } \\
\text { Sig }\end{array}$ & $\begin{array}{l}\text { NOT } \\
\text { Sig }\end{array}$ & $\begin{array}{l}\text { NOT } \\
\text { Sig }\end{array}$ & $\begin{array}{l}\text { NOT } \\
\text { Sig }\end{array}$ & $\begin{array}{l}\text { NOT } \\
\text { Sig }\end{array}$ & $\begin{array}{l}\text { NOT } \\
\text { Sig }\end{array}$ \\
\hline
\end{tabular}

Table 5. Constraints for optimization for independent variables/ dependent variables by design Expert 10.0.1.

\begin{tabular}{|c|c|c|c|c|c|c|}
\hline $\begin{array}{l}\text { Constraints } \\
\text { Name }\end{array}$ & Goal & Lower Limit & Upper Limit & Lower Weight & Upper Weight & Importance \\
\hline $\mathrm{X}_{1}$ :Enzyme Ratio (Naringinase:Tannase) & is in range & -1 & 1 & 1 & 1 & 3 \\
\hline $\mathrm{X}_{2}:$ Temperature $\left({ }^{\circ} \mathrm{C}\right)$ & is in range & -1 & 1 & 1 & 1 & 3 \\
\hline $\mathrm{X}_{3}$ : Time (hrs) & is in range & -1 & 1 & 1 & 1 & 3 \\
\hline $\mathrm{pH}$ & is in range & 3 & 3.4 & 1 & 1 & 3 \\
\hline TSS $\left({ }^{\circ}\right.$ Brix $)$ & minimize & 6.1 & 8.8 & 1 & 1 & 3 \\
\hline TA (\% citric acid) & is in range & 0.84 & 0.99 & 1 & 1 & 3 \\
\hline Naringine content $(\mu \mathrm{g} / \mathrm{ml})$ & minimize & 213.8 & 686.5 & 1 & 1 & 5 \\
\hline Tannin content $(\mathrm{mg} / \mathrm{ml})$ & minimize & 0.31 & 0.68 & 1 & 1 & 4 \\
\hline $\begin{array}{l}\text { TPC } \\
(\mathrm{mgGAE} / \mathrm{L})\end{array}$ & is in range & 1048 & 1822.8 & 1 & 1 & 3 \\
\hline $\begin{array}{l}\text { Vitamin C Content } \\
(\mathrm{mg} / 100 \mathrm{ml})\end{array}$ & is in range & 24.5 & 58.2 & 1 & 1 & 3 \\
\hline
\end{tabular}

Table 6. Coefficients for different responses by design Expert 10.0.1.

\begin{tabular}{|c|c|c|c|c|c|c|c|}
\hline \multirow[t]{2}{*}{ Factor } & \multicolumn{7}{|c|}{ Coefficients } \\
\hline & $\mathbf{p H}$ & $\begin{array}{c}\text { TSS } \\
{ }^{\circ} \text { Brix }\end{array}$ & $\begin{array}{l}\text { TA } \\
\%\end{array}$ & $\begin{array}{c}\text { Naringine Content } \\
(\mu \mathrm{g} / \mathrm{ml})\end{array}$ & $\begin{array}{l}\text { Tannin Content } \\
(\mathrm{mg} / \mathrm{ml})\end{array}$ & $\begin{array}{c}\text { TPC } \\
(\text { mgGAE/L) }\end{array}$ & $\begin{array}{c}\text { Vit C } \\
\text { Content } \\
(\mathrm{mg} / \mathbf{1 0 0 m l})\end{array}$ \\
\hline Intercept & 3.28 & 7.26 & 0.96 & 328.8 & 0.494 & 1109.64 & 25.54 \\
\hline $\begin{array}{c}\mathrm{X}_{1} \\
\text { Enzyme Ratio (Nringinase: Tannase) }\end{array}$ & $0.0375^{* *}$ & $-1.162^{* * *}$ & $-0.012 * *$ & $118.713^{* * *}$ & $-0.05^{* * *}$ & $-163.412 * * *$ & $-2.1125 * * *$ \\
\hline $\begin{array}{c}\mathbf{X}_{2} \\
\text { (Incubation Temperature) }\end{array}$ & $0.0375^{* *}$ & -0.037 & $-0.0087^{*}$ & $-95.075 * * *$ & $-0.08375^{* * *}$ & -27.9 & $-3.7625 * * *$ \\
\hline (Incubation Time) & $-0.05^{* * *}$ & -0.025 & 0.0062 & -15.4375 & $-0.01125^{*}$ & $53.3375^{* *}$ & $-2.575 * * *$ \\
\hline $\mathbf{X}_{1} \mathbf{X}_{2}$ & $-0.075 * * *$ & 0.075 & $-0.015^{* *}$ & $37.45^{* * *}$ & $-0.035 * * *$ & -29.25 & -0.4 \\
\hline $\mathbf{X}_{1} \mathbf{X}_{3}$ & $-0.15^{* * *}$ & $0.15 * *$ & $-1.124 \times 10^{-18}$ & -10.525 & $-0.025 * *$ & 37.575 & $-2.175 * *$ \\
\hline $\mathbf{X}_{2} \mathbf{X}_{3}$ & $1.088 \times 10^{-16}$ & $-0.2 * * *$ & -0.0025 & 12.9 & $-0.0275^{* *}$ & -33.9 & -0.625 \\
\hline $\mathrm{X}_{1}^{2}$ & $-0.1025^{* * * *}$ & $0.4825 * * *$ & $-0.0187 * *$ & $190.988^{* * *}$ & $0.13425 * * *$ & $393.492 * * *$ & $20.905^{* * * *}$ \\
\hline $\mathbf{X}_{2}^{2}$ & $-0.0525^{* *}$ & $-0.217 * * *$ & $0.02375^{* * *}$ & $-32.1875^{*}$ & $-0.04825 * * *$ & $195.417 * * *$ & $6.855^{* * *}$ \\
\hline $\mathrm{X}_{3}^{2}$ & -0.0275 & $-0.442 * * *$ & $-0.09125 * * *$ & 6.6875 & -0.00325 & -29.0075 & $5.13 * * *$ \\
\hline
\end{tabular}

***,**** Significant at 1,5 and $10 \%$ level of significance respectively 
The $\mathrm{F}$ value (170.08) for the model was significant at $1 \%$, i.e., $\mathrm{p}<0.01$ level of significance. Correlation coefficient $\mathrm{R}$ measures the generosity of fit of the model. $\mathrm{R}^{2}$ value for TSS was $99.54 \%$, which means that the model could account for $99.54 \%$ of data. The model does not elucidate $0.46 \%$ variation. The Pred R-Squared of $94.04 \%$ was in equitable agreement with the Adj R-Squared of $98.96 \%$. LOF was insignificant; hence, the second-order model was acceptable in describing TSS. The variation in TSS value for debittered juice was observed from 6.1 to 8.8 (table 3). The TSS score was found minimum (6.1) at the level of $\mathrm{X}_{1}(0: 100)$, $\mathrm{X}_{2}\left(40^{\circ} \mathrm{C}\right)$, and $\mathrm{X}_{3}(2 \mathrm{hrs})$.

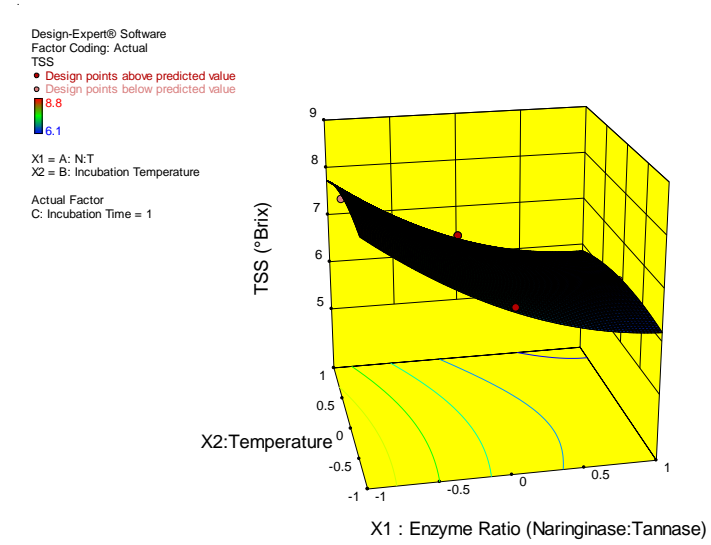

(i)

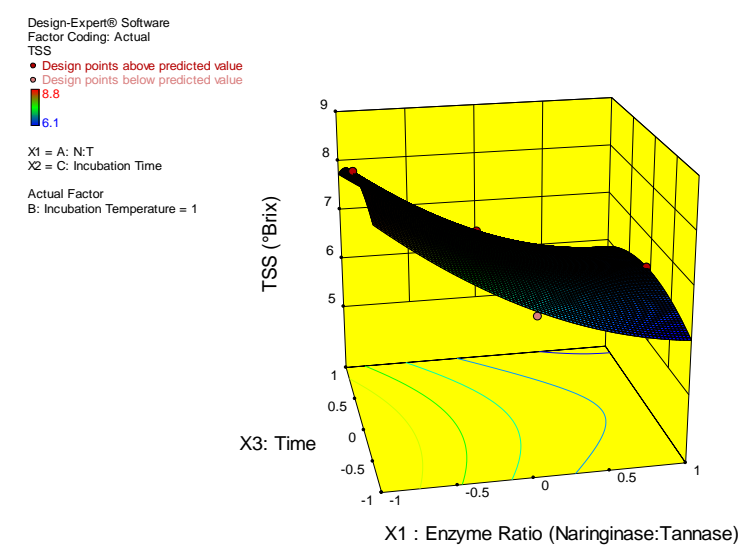

(ii)

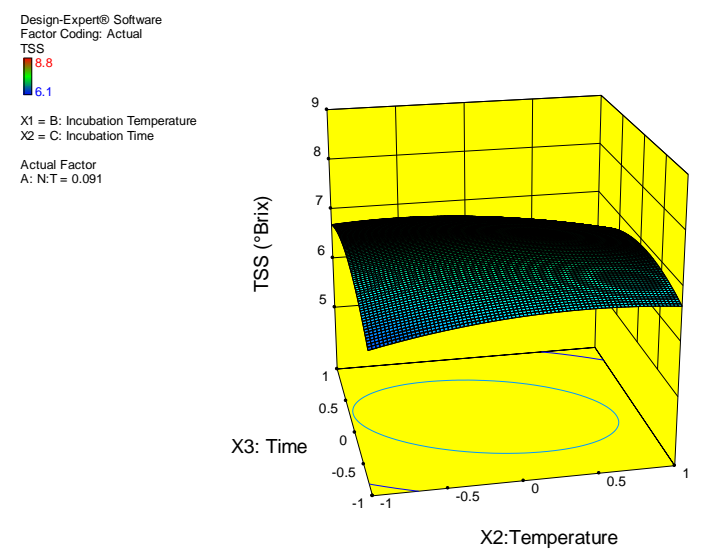

(iii)

Figure 2. 3D Response surface showing interaction effect of variables on TSS of debittered Citrus maxima juice i) temperature and enzyme ratio ii) time and enzyme ratio and iii) time and temperature.

The 3D response surface curve for TSS was presented in figure. 2 (i, ii \& iii). The values presented in Table 3 show that there were significant changes in TSS of the debittered juice (6.1-8.8). Figure 2 (i) shows that as temperature increase $\left(30^{\circ} \mathrm{C}\right.$ to $\left.50^{\circ} \mathrm{C}\right)$, TSS was decreased in the presence of enzyme ratio. Figure 2 (ii) showed that the TSS decreased as time increased (2-4 hrs) with different enzyme ratio levels. Figure 2 (iii) depicted that the TSS increased along with an increasing level of time and temperature. Our finding favors the finding of [45].

From table 6 of the coefficient, it was observed that $\mathrm{X}_{1}$ (enzyme ratio) at $1 \%$ level, i.e., $\mathrm{p}<0.01$ of significance, $\mathrm{X}_{2}$ (temperature), and $\mathrm{X}_{3}$ (time) had a negative effect on TSS at a linear level. Interactive effect of $\mathrm{X}_{2}$ (temperature), $\mathrm{X}_{3}$ (time) had significant negative effect at $1 \%$ level i.e. $\mathrm{p}<0.01$ of significance while $\mathrm{X}_{1}$ (enzyme ratio), $\mathrm{X}_{2}$ (temperature) had positive effect at more than $10 \%$ level $(\mathrm{p}<0.1)$ of significance whereas $\mathrm{X}_{1}$ (enzyme ratio), $\mathrm{X}_{3}$ (time) had positive effect at $5 \%$ level $(\mathrm{p}<0.05)$ of significance. Quadratic effect of $\mathrm{X}_{1}$ (enzyme ratio) was 
positive at $1 \%$ level $(\mathrm{p}<0.01)$ of significance, while $\mathrm{X}_{2}$ (temperature) and $\mathrm{X}_{3}$ (time) was negative at 1 level \% $(\mathrm{p}<0.01)$.

\subsection{Effect on $T A$.}

Full second order equation to show the effect of $X_{1}, X_{2}$, and $X_{3}$ on TA could be explained by the equation given below.

$\mathrm{TA}=0.96-0.012 \mathrm{X}_{1}-8.75 \times 10^{-3} \mathrm{X}_{2}+6.250 \times 10^{-3} \mathrm{X}_{3}-0.015 \mathrm{X}_{1} \mathrm{X}_{2}-1.124 \times 10^{-18} \mathrm{X}_{1} \mathrm{X}_{3}-$ $2.50 \times 10^{-3} \mathrm{X}_{2} \mathrm{X}_{3}-0.018750 \mathrm{X}_{1}^{2}+0.023750 \mathrm{X}_{2}^{2}-0.091250 \mathrm{X}_{3}^{2}$

The total effect of individual parameters on TA at linear, quadratic, and interactive levels is reported in Table 4 The $\mathrm{F}$ value (37.17) for the model was significant at $1 \%$, i.e., $\mathrm{p}<0.01$ level of significance. Correlation coefficient $\mathrm{R}^{2}$ measures the generosity of fit of the regression model. $\mathrm{R}^{2}$ value for TA was $97.95 \%$, which means that the model could account for 97.95\% of data, and $2.05 \%$ variation is not elucidated by the model. The Pred R-Squared of $80.74 \%$ was an in equitable agreement with the Adj R-Squared of $95.32 \%$. LOF was insignificant; hence, a second-order model was adequate in describing TA. The variation in TA value for debittered juice was observed from 0.84 to 0.99 (table 3 ). The TA score was found maximum (0.99) at the level of $\mathrm{X}_{1}(100: 0), \mathrm{X}_{2}\left(50^{\circ} \mathrm{C}\right)$, and $\mathrm{X}_{3}(3 \mathrm{hrs})$.

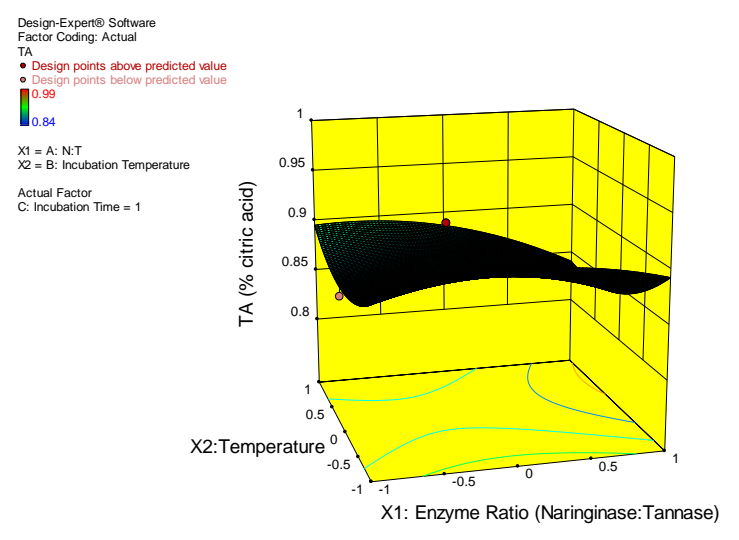

(i)

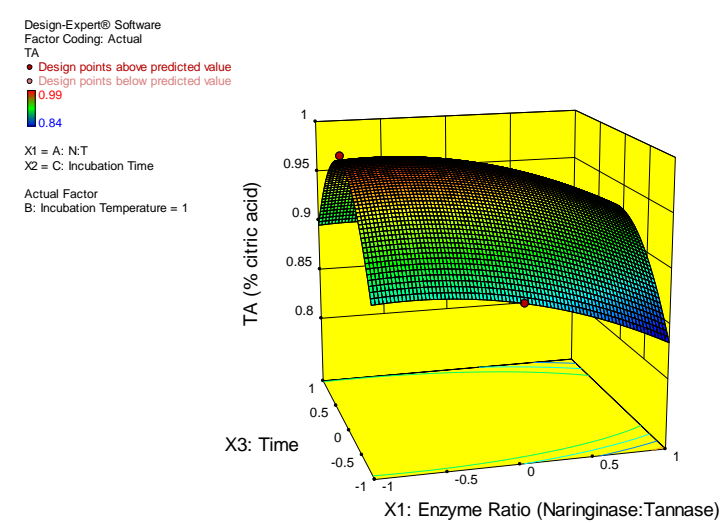

(ii)

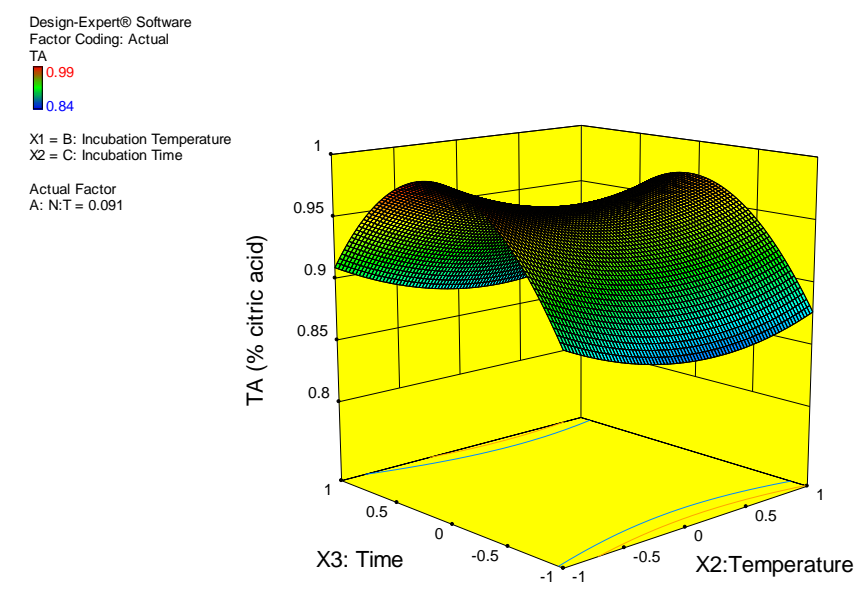

(iii)

Figure 3. 3D Response surface showing interaction effect of variables on TA of debittered Citrus maxima juice i) temperature and enzyme ratio ii) time and enzyme ratio and iii) time and temperature. 
The 3D response surface curve for TA was presented in the figure. 3 (i, ii \& iii). The values presented in Table 3 show that there were significant changes in TA of the debittered juice (0.84- 0.99). Figure 3 (i) shows that as temperature increase $\left(30^{\circ} \mathrm{C}\right.$ to $\left.50^{\circ} \mathrm{C}\right) \mathrm{TA}$ was first decreased slightly and then increased slightly in the presence of enzyme ratio. Figure 3 (ii) showed that the TA increased as time increase and maximum at a central point $\left(\mathrm{X}_{3}=3 \mathrm{hr}\right)$ and then decreased very rapidly as the time increased (3-4 hrs.) with different levels of enzyme ratio. From figure 3 (iii), it is clearly depicted that the TA increased as time increase and maximum at the central point $\left(\mathrm{X}_{3}=3 \mathrm{hr}\right)$ and then decreased very rapidly as the time increased (3-4 hrs.) with an increasing level of temperature. Our finding favors the finding of [44], who observed no significant TA changes during enzymatic treatment of pomegranate juice.

From table 6 of coefficient, it was observed that $X_{1}$ (enzyme ratio) at $5 \%$ level, i.e., $\mathrm{p}<0.05$ of significance, $\mathrm{X}_{2}$ (Temperature) at $1 \%$ level, i.e., $\mathrm{p}<0.01$ of significance had a negative effect on TA at a linear level while $\mathrm{X}_{3}$ (Time) had a positive effect on TA at a linear level. Interactive effect of $\mathrm{X}_{1}$ (enzyme ratio), $\mathrm{X}_{2}$ (Temperature) had a significant negative effect at $5 \%$ level i.e., $\mathrm{p}<0.05$ of significance and $\mathrm{X}_{1}$ (enzyme ratio), $\mathrm{X}_{3}$ (Time) and $\mathrm{X}_{2}$ (Temperature), $\mathrm{X}_{3}$ (Time) also had a significant negative effect at more than $10 \%$ level $(\mathrm{p}<0.1)$ of significance. Quadratic effect of $\mathrm{X}_{1}$ (enzyme ratio) and $\mathrm{X}_{3}$ (Time) was negative at $5 \%$ level $(\mathrm{p}<0.05)$ and $1 \%$ level $(\mathrm{p}<0.01)$ of significance respectively, while $\mathrm{X}_{2}$ (Temperature) and was positive at 1 level \% $(\mathrm{p}<0.01)$ of significance.

\subsection{Effect on naringin content.}

Full second order equation to show the effect of $X_{1}, X_{2}$, and $X_{3}$ on naringin content could be explained by the equation given below.

Naringin Content $=328.80+118.7 \mathrm{X}_{1}-95.08 \mathrm{X}_{2}-15.44 \mathrm{X}_{3}+37.45 \mathrm{X}_{1} \mathrm{X}_{2}-10.52 \mathrm{X}_{1} \mathrm{X}_{3}+12.90$ $\mathrm{X}_{2} \mathrm{X}_{3}+190.99 \mathrm{X}_{12}-32.19 \mathrm{X}_{22}+6.69 \mathrm{X}_{32}$

The $\mathrm{F}$ value (42.54) for the model was significant at $1 \%$, i.e., $\mathrm{p}<0.01$ level of significance. Correlation coefficient $\mathrm{R}$ measures the generosity of fit of the regression model. The $\mathrm{R}_{2}$ value for naringin content was $98.20 \%$, which means that the model could account for $98.20 \%$ of data, and $1.8 \%$ variation is not explained by the model. The Pred R-Squared of 88.48 $\%$ was in equitable agreement with the Adj R-Squared of $95.90 \%$. Lack of fit was insignificant; therefore, a second-order model was acceptable in describing naringin content. The variation in naringin content value for debittered juice was observed from 686.5 to 213.8 (table 3). The naringin content was found minimum (213.8) at the level of $\mathrm{X}_{1}(100: 0), \mathrm{X}_{2}\left(50^{\circ} \mathrm{C}\right)$, and $\mathrm{X}_{3}(3$ hrs).

The 3D response surface curve for naringin content was presented in figure 4 (i, ii \& iii). The values presented in Table 3 show that there were significant changes in the naringin content of the debittered juice (686.5-213.8). Figure 4 (i) shows that as temperature increase $\left(30^{\circ} \mathrm{C}\right.$ to $\left.50^{\circ} \mathrm{C}\right)$, naringin content was decreased significantly. With respect to enzyme ratio, naringin content was lower with naringinase enzyme. There was no decrement in naringin content with tannase enzyme in enzyme ratio. Figure 4 (ii) showed that the naringin content value was lower with the naringinase enzyme with time with respect to enzyme ration. Figure 4 (iii) clearly depicted that the naringin content decreased as time and temperature increased. A similar finding was observed by [46-49], who observed that the naringin content in grapefruit juice and pomelo juice respectively was decreased when the juice sample was treated with naringinase. 


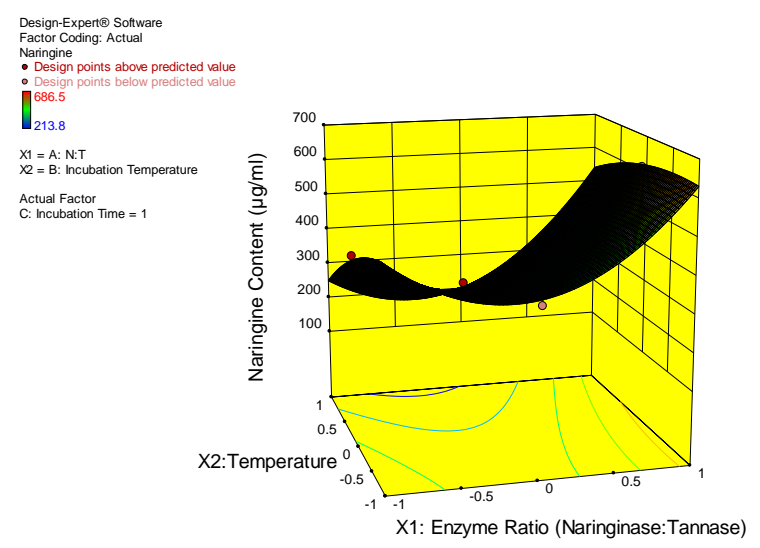

(i)

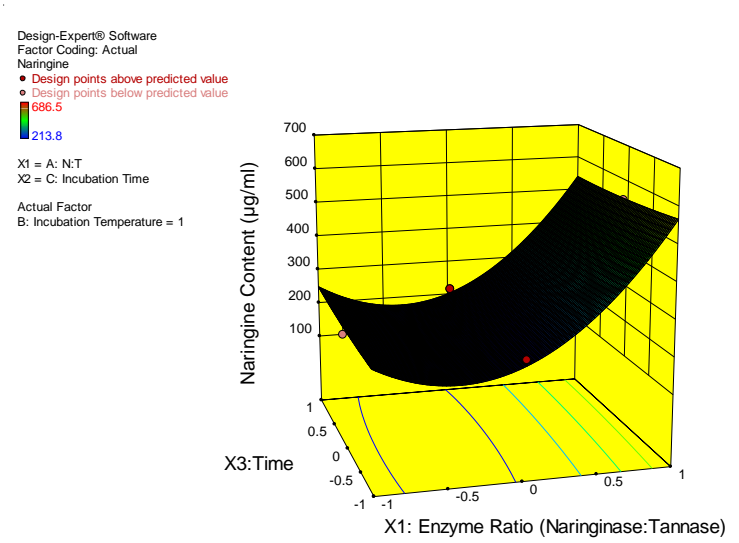

(ii)

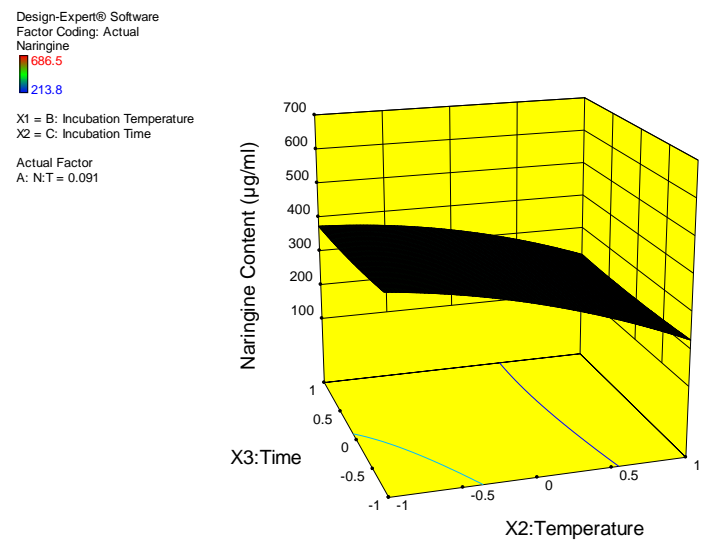

(iii)

Figure 4. 3D Response surface showing interaction effect of variables on naringin content of debittered Citrus maxima juice i) temperature and enzyme ratio ii) time and enzyme ratio and iii) time and temperature.

From table 6 of coefficient, it was observed that $\mathrm{X}_{1}$ (enzyme ratio) had a positive effect on naringin content at $1 \%$ level, i.e., $\mathrm{p}<0.01$ of significance at a linear level, while $\mathrm{X}_{2}$ (Temperature) and $\mathrm{X}_{3}$ (Time) had a negative effect at $1 \%$ level, i.e., $\mathrm{p}<0.01$ and more than 10 $\%$ level, i.e., $\mathrm{p}<0.1$ of significance respectively. Interactive effect of $\mathrm{X}_{1}$ (enzyme ratio), $\mathrm{X}_{2}$ (Temperature), and $\mathrm{X}_{2}$ (Temperature), $\mathrm{X}_{3}$ (Time) had a significant positive effect at $5 \%$ level $(\mathrm{p}<0.05)$ and more than $10 \%$ level, i.e., $\mathrm{p}<0.1$ of significance respectively. Quadratic effect of $\mathrm{X}_{1}$ (enzyme ratio) and $\mathrm{X}_{3}$ (Time) was positive at $1 \%$ level $(\mathrm{p}<0.01)$ and more than $10 \%$ level $(\mathrm{p}<0.1)$ of significance respectively, while $\mathrm{X}_{2}$ (Temperature) and was negative at $10 \%$ level $(\mathrm{p}<0.1)$ of significance.

\subsection{Effect on tannin content.}

Complete second-order equation produced in terms of $\mathrm{X}_{1}, \mathrm{X}_{2}$, and $\mathrm{X}_{3}$ for the effect of enzyme ratio, temperature, and time on tannin content could be explained by the equation given below.

Tannin Content $=0.49-0.050 \mathrm{X}_{1}-0.084 \mathrm{X}_{2}-0.011 \mathrm{X}_{3}-0.035 \mathrm{X}_{1} \mathrm{X}_{2}-0.025 \mathrm{X}_{1} \mathrm{X}_{3}-0.028 \mathrm{X}_{2}$ $\mathrm{X}_{3}+0.13 \mathrm{X}_{1}^{2}-0.048 \mathrm{X}_{2}^{2}-3.250 \times 10^{-3} \mathrm{X}_{3}^{2}$

The F value (76.04) for the model was significant at a $1 \%(\mathrm{p}<0.01)$ level of significance. Correlation coefficient $\mathrm{R}^{2}$ measures the generosity of fit of the regression model. The $\mathrm{R}^{2}$ value for tannin content was $98.90 \%$, which means that the model could account for $98.90 \%$ of data, and the model does not elucidate $1.1 \%$ variation. The $\mathrm{R}^{2}$ value higher than $90 \%$ meant that the 
regression model explained the reaction well. The Pred R-Squared of $86.48 \%$ was in equitable agreement with the Adj R-Squared of $97.69 \%$. Lack of fit was insignificant; hence, a secondorder model was acceptable in describing naringin content. The tannin content value variation for debittered juice was observed from 0.68 to 0.31 (table 3 ). The tannin content was found minimum (0.31) at the level of $\mathrm{X}_{1}(50: 50), \mathrm{X}_{2}\left(50^{\circ} \mathrm{C}\right)$, and $\mathrm{X}_{3}(4 \mathrm{hrs})$.

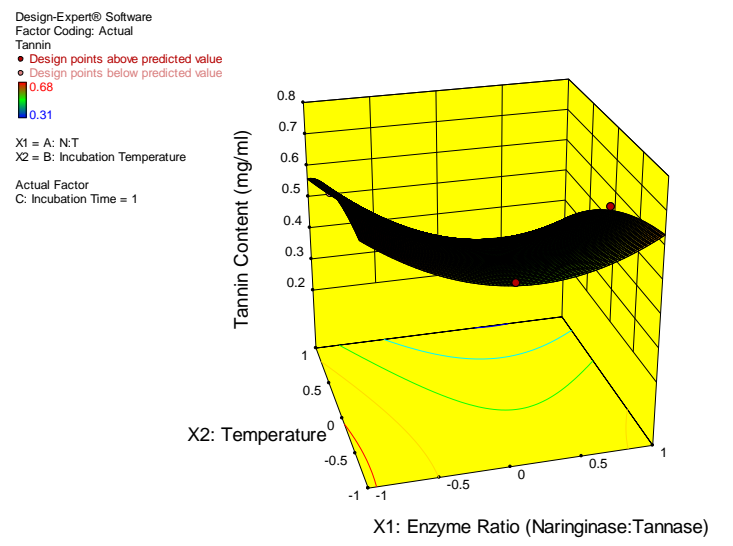

(i)

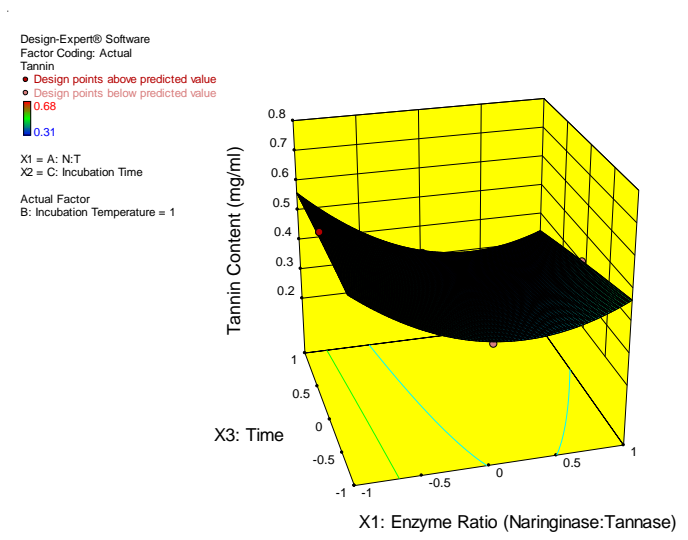

(ii)

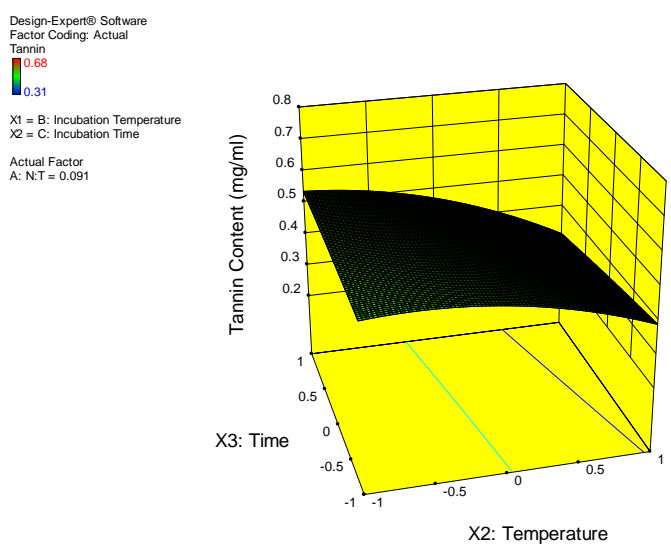

(iii)

Figure 5. 3D Response surface showing interaction effect of variables on the tannin content of debittered Citrus maxima juice i) temperature and enzyme ratio ii) time and enzyme ratio and iii) time and temperature.

The 3D response surface curve for tannin content was presented in figure 5 (i, ii \& iii). The values presented in Table 3 show that there were significant changes in the tannin content of the debittered juice $(0.68-0.31)$. Figure 5 (i) shows that as temperature increase $\left(30^{\circ} \mathrm{C}\right.$ to $50^{\circ} \mathrm{C}$ ), tannin content was decreased significantly. With respect to enzyme ratio, there was no change in tannin content with the naringinase enzyme. There was a significant change in tannin content with tannase enzyme in enzyme ratio. Figure 5 (ii) showed that the tannin content decreased significantly with an increase in time, and tannin content was also decreased with tannase enzyme in enzyme ratio. Figure 5 (iii), it is depicted that the tannin content decreased as temperature increased. Our findings favor the findings of [50-52].

From table 6 of coefficient, it was observed that $\mathrm{X}_{1}$ (enzyme ratio), $\mathrm{X}_{2}$ (Temperature), and $\mathrm{X}_{3}$ (Time) had a negative effect on tannin content at $1 \%$ level $(\mathrm{p}<0.01), 1 \%$ level $(\mathrm{p}<0.01)$ and $10 \%$ level $(\mathrm{p}<0.1)$ of significance respectively. Interactive effect of $\mathrm{X}_{1}$ (enzyme ratio), $\mathrm{X}_{2}$ (Temperature) and $\mathrm{X}_{1}$ (enzyme ratio), $\mathrm{X}_{3}$ (Time) and $\mathrm{X}_{2}$ (Temperature), $\mathrm{X}_{3}$ (Time) had significant negative effect at $1 \%$ level $(\mathrm{p}<0.01), 5 \%$ level $(\mathrm{p}<0.05)$ and $5 \%$ level $(\mathrm{p}<0.05)$ of significance respectively. Quadratic effect of $\mathrm{X}_{1}$ (enzyme ratio) was positive at $1 \%$ level 
$(\mathrm{p}<0.01)$ of significance. In comparison, $\mathrm{X}_{2}$ (Temperature) was negative at $1 \%$ level $(\mathrm{p}<0.01)$ of significance, but the quadratic effect of $\mathrm{X}_{3}$ (Time) was positive at more than $10 \%$ level $(\mathrm{p}<0.1)$ of significance.

\subsection{Effect on TPC.}

Full second order equation to show the effect of $\mathrm{X}_{1}, \mathrm{X}_{2}$, and $\mathrm{X}_{3}$ on TPC could be explained by the equation given below.

$\mathrm{TPC}=1109.64-163.41 \mathrm{X}_{1}-27.90 \mathrm{X}_{2}+53.34 \mathrm{X}_{3}-29.25 \mathrm{X}_{1} \mathrm{X}_{2}+37.57 \mathrm{X}_{1} \mathrm{X}_{3}-33.90 \mathrm{X}_{2} \mathrm{X}_{3}+$ $393.49 \mathrm{X}_{1}^{2}+195.42 \mathrm{X}_{2}^{2}-29.01 \mathrm{X}_{3}^{2}$

The $\mathrm{F}$ value (47.76) for the model was significant at $1 \%$, i.e., $\mathrm{p}<0.01$ level of significance. Correlation coefficient $\mathrm{R}$ measures the goodness of fit of the regression model. $\mathrm{R}^{2}$ value for TPC was $98.40 \%$, which implies that the model could account for $98.40 \%$ of data, and the model does not explain 1.6\% variation. The Pred R-Squared of $80.47 \%$ was in equitable agreement with the Adj R-Squared of $96.34 \%$. Lack of fit was insignificant; therefore, a second-order model was acceptable in describing naringin content. The variation in TPC value for debittered juice was observed from 1048 to 1822.8 (table 3). The TPC was found minimum (1048.0) at the level of $\mathrm{X}_{1}(50: 50), \mathrm{X}_{2}\left(40^{\circ} \mathrm{C}\right)$, and $\mathrm{X}_{3}(3 \mathrm{hrs})$.

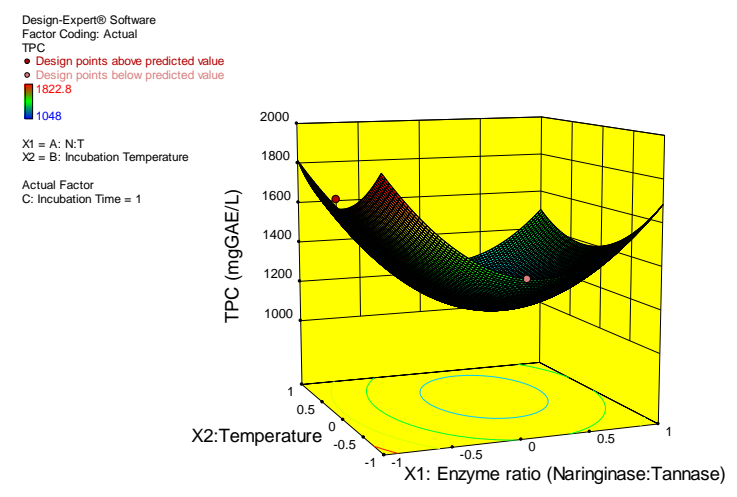

(i)

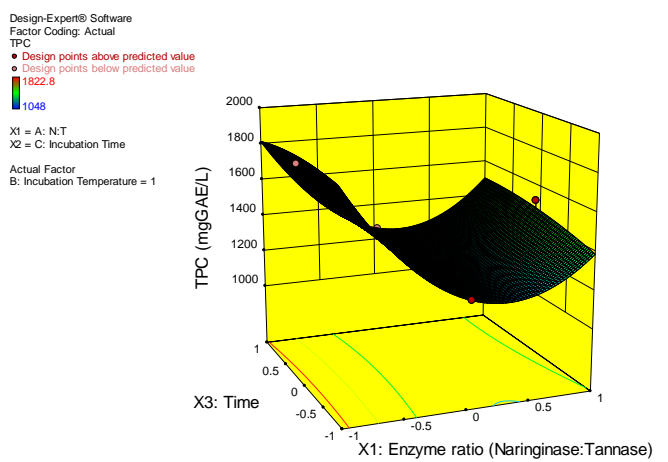

(ii)

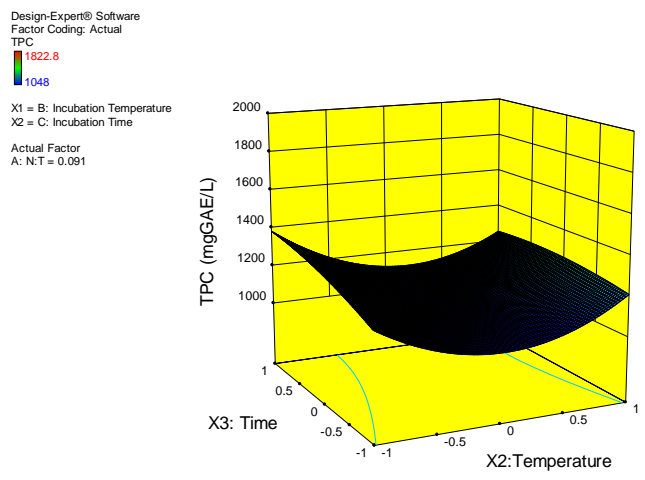

(iii)

Figure 6. 3D Response surface showing interaction effect of variables on TPC of debittered Citrus maxima juice, i) temperature and enzyme ratio ii) time and enzyme ratio and iii) time and temperature.

The 3D response surface curve for TPC was presented in figure 6 (i, ii \& iii). The values presented in Table 3 show that there were significant changes in TPC of the debittered juice $(1048.0-1822.8)$. Figure 6 (i) shows that TPC increased with the enzyme ratio as temperature increase $\left(30^{\circ} \mathrm{C}\right.$ to $\left.50^{\circ} \mathrm{C}\right)$. Figure 6 (ii) showed that the TPC increased significantly with an 
increase in time while decreased with tannase enzyme with respect to enzyme ratio. Figure 6 (iii) depicted that the TPC increased as incubation time and incubation temperature increased. This increment in TPC could be co-related with the presence of naringenin (i.e., a metabolite produced from naringin with hydroxyl groups) or, due to the possibility of overestimation of polyphenolic content with respect to lack of selectivity of Folin-Ciocalteu's reagent [53], when analyzed through the spectrophotometric method. It also shows that Folin-Ciocalteu's reagent reacts with reducing compounds like sugars (e.g., glucose) and not only reacts with phenols[54]. Our findings favor the findings of Cavia-Saiz [55, 49], who observed that the total phenolic content was increased as the naringinase concentration increases.

From table 6 of coefficient, it was observed that $\mathrm{X}_{1}$ (enzyme ratio) and $\mathrm{X}_{2}$ (Temperature) had a negative effect on TPC at $1 \%$ level $(\mathrm{p}<0.01)$ and more than $10 \%$ level $(\mathrm{p}<0.1)$ of significance, respectively while $\mathrm{X}_{3}$ (Time) had positively effect on TPC at $5 \%$ level $(\mathrm{p}<0.05)$ of significance. Interactive effect of $\mathrm{X}_{1}$ (enzyme ratio), $\mathrm{X}_{2}$ (Temperature) and $\mathrm{X}_{2}$ (Temperature), $\mathrm{X}_{3}$ (Incubation Time) had a significant negative effect at more than $10 \%$ level $(\mathrm{p}<0.1)$ of significance while $\mathrm{X}_{1}$ (enzyme ratio), $\mathrm{X}_{3}$ (Incubation Time) was positive at more than $10 \%$ level $(\mathrm{p}<0.1)$ of significance. Quadratic effect of $\mathrm{X}_{1}$ (enzyme ratio) and $\mathrm{X}_{2}$ (Temperature) was positive at $1 \%$ level $(\mathrm{p}<0.01)$ of significance, while $\mathrm{X}_{3}$ (Time) was negative at more than $10 \%$ level $(\mathrm{p}<0.1)$ of significance.

\subsection{Effect on vitamin C content.}

Complete second-order equation produced in terms of $\mathrm{X}_{1}, \mathrm{X}_{2}$, and $\mathrm{X}_{3}$ for the effect of enzyme ratio, temperature, and time on Vitamin $\mathrm{C}$ content could be explained by the equation given below.

Vitamin C Content $=25.54-2.11 \mathrm{X}_{1}-3.76 \mathrm{X}_{2}-2.58 \mathrm{X}_{3}-0.4 \mathrm{X}_{1} \mathrm{X}_{2}-2.17 \mathrm{X}_{1} \mathrm{X}_{3}-0.63 \mathrm{X}_{2} \mathrm{X}_{3}$ $+20.91 \mathrm{X}_{1}^{2}+6.85 \mathrm{X}_{2}^{2}+5.13 \mathrm{X}_{3}^{2}$

The F value (147.9) for the model was significant at $1 \%(\mathrm{p}<0.01)$ level of significance. Correlation coefficient $\mathrm{R}^{2}$ measures the generosity of fit of the model. The $\mathrm{R}^{2}$ value for TPC was $99.48 \%$, which means that the model could account for $99.48 \%$ of data, and the model does not elucidate $0.52 \%$ variation. The Pred R-Squared of $94.68 \%$ was in equitable agreement with the Adj R-Squared of $98.80 \%$. Lack of fit was insignificant; hence, a second-order model was acceptable in describing Vitamin $\mathrm{C}$ content. The variation in vitamin $\mathrm{C}$ content value for debittered juice was observed from 58.2 to 24.5 (table 3). The vitamin $\mathrm{C}$ content was found maximum (58.2) at the level of $\mathrm{X}_{1}(100: 0), \mathrm{X}_{2}\left(30^{\circ} \mathrm{C}\right)$, and $\mathrm{X}_{3}(3 \mathrm{hrs})$.

The 3D response surface curve for vitamin $\mathrm{C}$ content was presented in figure 7 (i, ii \& iii). The values presented in table 4 show that there were significant changes in vitamin $\mathrm{C}$ content of the debittered juice $(24.5$ - 58.2). Figure 7 (i) shows that as temperature increase $\left(30^{\circ} \mathrm{C}\right.$ to $\left.50^{\circ} \mathrm{C}\right)$, vitamin $\mathrm{C}$ content was decreased with enzyme ratio. Figure 7 (ii) showed that vitamin $\mathrm{C}$ content decreased significantly with an increase in enzyme ratio time. Figure 7 (iii) depicted that the vitamin $\mathrm{C}$ content decreased as time and temperature increased. The vitamin $\mathrm{C}$ content was found to increase near the central valve of enzyme concentration. The decrease in response (ascorbic acid content) may be due to the denaturation of the enzyme at high temperatures. A similar finding was reported by [56-57], who observed that the ascorbic acid content decreases as the temperature and time increases, respectively.

From table 6 of the coefficient, it was observed that $\mathrm{X}_{1}$ (enzyme ratio), $\mathrm{X}_{2}$ (Temperature), and $\mathrm{X}_{3}$ (Time) had a negative effect on vitamin $\mathrm{C}$ content at a $1 \%$ level $(\mathrm{p}<0.01)$ of significance. The interactive effect of $\mathrm{X}_{1}$ (enzyme ratio), $\mathrm{X}_{3}$ (Time) had a significant 
negative effect at a $5 \%$ level $(\mathrm{p}<0.05)$ of significance. Quadratic effect of $\mathrm{X}_{1}$ (enzyme ratio), $\mathrm{X}_{2}$ (Temperature), and $\mathrm{X}_{3}$ (Time) were positive at $1 \%$ level $(\mathrm{p}<0.01)$ of significance.

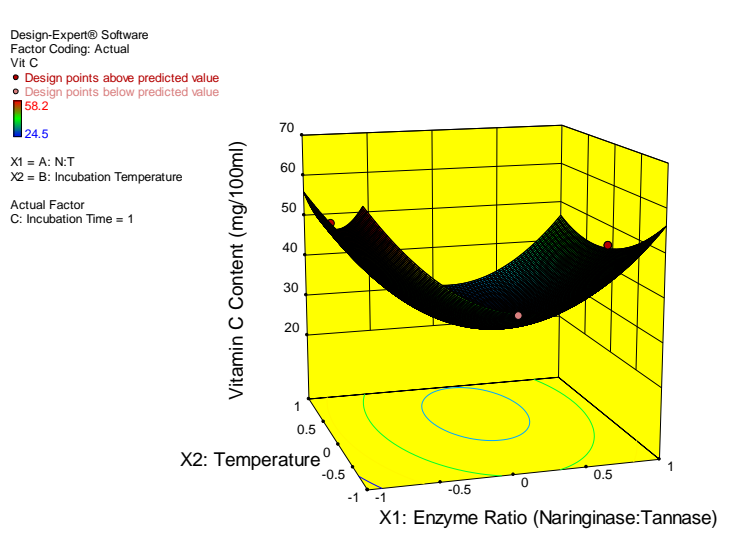

(i)

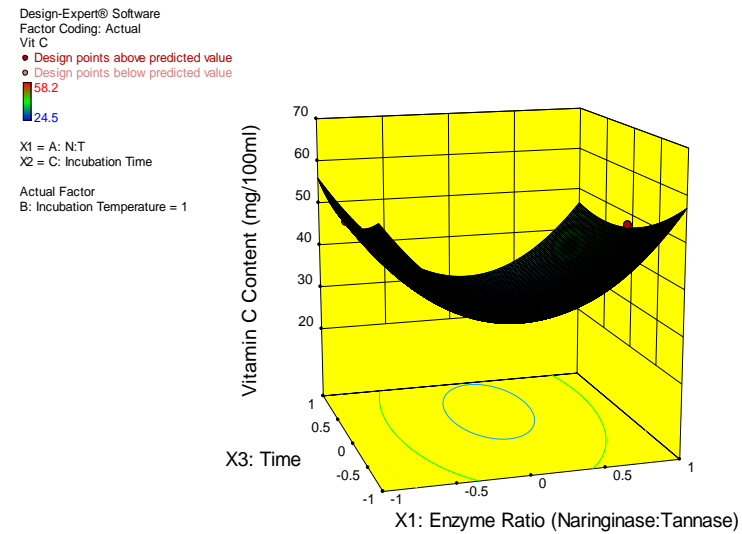

(ii)

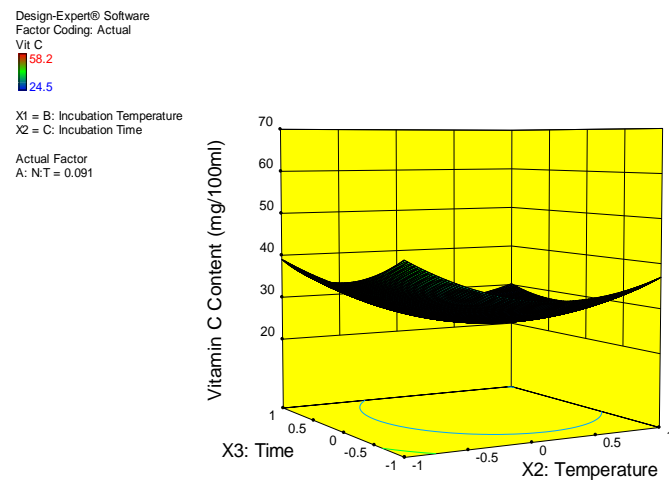

(iii)

Figure 7. 3D Response surface showing interaction effect of variables on Vitamin $\mathrm{C}$ content of debittered Citrus maxima juice i) temperature and enzyme ratio ii) time and enzyme ratio and iii) time and temperature.

\section{Conclusions}

The model $\mathrm{F}$ value was found to be highly significant at a $1 \%$ level of significance for all the responses. The second-order model could be fitted to predict the entire dependent parameters. The optimum values for debittering and clarification of citrus maxima juice were found to be $54.55: 45.45,50^{\circ} \mathrm{C}$, and $4 \mathrm{hrs}$. The values for $\mathrm{pH}$, TSS, TA, Naringin content, Tannin content, TPC and Vitamin C content were found to be $3.17,6.256^{\circ} \mathrm{Brix}, 0.885 \%$ citric acid, $220.549 \mu \mathrm{g} / \mathrm{ml}, 0.311 \mathrm{mg} / \mathrm{ml}, 1256.721 \mathrm{mg} \mathrm{GAE} / \mathrm{L}, 30.309 \mathrm{mg} / 100 \mathrm{ml}$ respectively. It could be concluded that the enzymatic debittering and clarification of citrus maxima juice could be done by immobilized enzymes naringinase and tannase, which is produced from Aspergillus sp. SK01 isolated from rotten Citrus maxima under optimum processing conditions.

\section{Funding}

This research received no external funding. 


\section{Acknowledgments}

The authors are thankful to the Department of Life Sciences, Graphic Era (Deemed-to-be) University, Dehradun, Uttarakhand, India, for permitting us to carry out the study at the University.

\section{Conflicts of Interest}

The authors declare no conflict of interest.

\section{References}

1. Morton, J. Pummelo Citrus maxima: Fruits of warm climates. Pummelo, 1987; pp.147-151.

2. Burda, S.; Oleszek, W. Antioxidant and antiradical activities of flavonoids. J Agri Food Chem 2001, 49, 2774-2779, https://doi.org/10.1021/jf001413m.

3. Fattouch, S.; Caboni, P.; Coroneo, V. Antimicrobial activity of Tunisian quince (Cydonia oblonga Miller) pulp and peel polyphenolic extracts. Journal of Agriculture and Food Chemistry 2007, 55, 963-969, https://doi.org/10.1021/jf062614e.

4. Montanari, A.; Chen, J.;Widmer, W. Citrus flavonoids: A review of past biological activity against disease. In: Flavonoids in the Living System. Manthey, J.A.; Buslig, B.S. (Eds.), New York: Plenum Press, 1998; pp. 103-113, https://doi.org/10.1007/978-1-4615-5335-9

5. Samman, S.;Wall, P. M. L.; Cook, N. C. Flavonoids and coronary heart disease: Dietary perspectives. In: Flavonoids in the Living System. Manthey, J.A.; Buslig, B.S. (Eds.), New York: Plenum Press, 1996; pp. 469-481.

6. Peace, N.A.; Happiness, C.A. Nutrient, phytochemical, and anti-nutrient composition of Citrus maxima fruit juice and peel extract. Food Science and nutrition 2018, 6, 653-658, https://doi.org/10.1002/fsn3.604.

7. Li, L.; Tan, W.; Li, W.; Zhu, Y.; Cheng, Y.; Ni, H. Citrus taste modification potentials by genetic engineering. Int. J. Mol. Sci. 2019, 20, https://doi.org/10.3390/ijms20246194.

8. Gupta, A.K.; Koch, P.; Mishra, P. Optimization of debittering and deacidification parameters for Pomelo juice and assessment of juice quality. $J$ Food Sci Technol 2020, 57, 4726-4732, https://doi.org/10.1007/s13197-020-04687-w.

9. Awad, G.E.A.; Abd El Aty, A.A.; Shehata, A.N.; Hassan, M.E.; Elnashar, M.M. Covalent immobilization of microbial naringinase using novel thermally stable biopolymer for hydrolysis of naringin. 3 Biotech 2016, 6, https://doi.org/10.1007/s13205-015-0338-x

10. Hasegawa, S.; Maier, V.P. Solution to the limonin bitterness problem of citrus juices. Food Technology 1993, 37, 73-77.

11. Pereira, G.A.; Arruda, H.S.; Morais, D.R.; Araujo, N.M.P.; Pastore, G.M. Mutamba (Guazuma ulmifolia Lam.) fruit as a novel source of dietary fibre and phenolic compounds. Food Chem 2020, 310, https://doi.org/10.1016/j.foodchem.2019.125857.

12. Singh, S.S.; Abdullah, S.; Pradhan, R.C.; Mishra, S. Physical, chemical, textural, and thermal properties of cashew apple fruit. Journal of Food Process Engineering 2019, 42, 1-10, https://doi.org/10.1111/jfpe.13094.

13. Singh, J.; Kundu, D.; Das, M.; Banerjee, R. Enzymatic processing of juice from fruits/vegetables: An emerging trend and cutting edge research in food biotechnology. In: Enzymes in food biotechnology. San Diego, California, USA: Academic Press 2019; pp. 419-432, https://doi.org/10.1016/B978-0-12-8132807.00024-4.

14. Aguilar, C.; Rodriguez, R.; Gutierrez-Sanchez, G.; Augur, C.; Favela-Torres, E.; Prado-Barragan, L.A.; Ramirez-Coronel, A.; Coteras-Esquivel, J.C. Microbial Tannases: advances and perspectives. Appl. Microbiol. Biotechnol 2007, 76, 47-59, https://doi.org/10.1007/s00253-007-1000-2

15. Rout, S.; Banerjee, R. Production of tannase under $\mathrm{mSSF}$ and its application in fruit juice debittering. Indian J Biotechnol 2006, 5, 351-356.

16. Patil, S.V.; Koli, S.H.; Mohite, B.V.; Patil, R.P.; Patil, R.R.; Borase, H.P.; Patil, V.S. A novel screening method for potential naringinase producing microorganisms. Biotechnol. Appl. Biochem 2019, 66, 323-327, https://doi.org/10.1002/bab.1728.

17. Arshad, R.; Mohyuddin, A.; Saeed, S.; Hassan, A.U. Optimized production of tannase and gallic acid from fruit seeds by solid state fermentation. Tropical Journal of Pharmaceutical Research 2019, 18, 911-918.

18. Chandler, B.V.; Nicol, K.J. Some relationships of naringin: their importance in orange juice bitterness. CSIRO Food Res Quart Volume 35, 1975; pp.79-88.

19. Habelt, K.; Pittner, F. A rapid method for the determination of naringin, prunin, and naringin applied to the assay of naringinase. Anal Biochem 1983, 134, 393-397, https://doi.org/10.1016/0003-2697(83)90314-7. 
20. Purewal, S.S.; Sandhu, K.S. Debittering of citrus juice by different processing methods: A novel approach for food industry and agro-industrial sector Scientia Horticulturae 2021, 276, https://doi.org/10.1016/j.scienta.2020.109750.

21. Yadav, V.; Yadav, P.K.; Yadav, S.; Yadav, K.D.S. $\alpha-1-$ Rhamnosidase: A review. Process Biochem 2010, 45, 1226-1235, https://doi.org/10.1016/j.procbio.2010.05.025.

22. Ono, M.; Tgsa, T.; Chibata, I. Preparation and properties of immobilized naringinase using tanninaminohexyl cellulose. Agric. Biol. Chem 1978, 42, 1847-1853, https://doi.org/10.1080/00021369.1978.10863264.

23. Vila-Reala, H.; Alfaia, A.J.; Rosa, M.E.; Calado, A.R.; Ribeiro, M.H.L. An innovative sol-gel naringinase bioencapsulation process for glycosides hydrolysis. Process Biochem 2010, 45, 841-850, https://doi.org/10.1016/j.procbio.2010.02.004.

24. Ribeiro, M.H. Naringinase: occurrence, characteristics, and applications. Appl. Microbiol. Biotechnol 2011, 90, 1883-1895. https://doi.org/10.1007/s00253-011-3176-8.

25. Sharma, K.P. Tannin degradation by phytopathogen's tannase: A Plant's defense perspective. Biocatalysis and Agricultural Biotechnology 2019, 21, https://doi.org/10.1016/j.bcab.2019.101342.

26. Purohit, J.S.; Dutta, J.R.; Nanda, R.K.; Banerjee, R. Strain improvement for tannase production from coculture of Aspergillus foetidus and Rhizopus oryzae. Bioresource Technol 2006, 97, 795-801, https://doi.org/10.1016/j.biortech.2005.04.031.

27. Abd El Tawab, A.M.; Murad, H.A.; Khattab, M.S.A.; Azzaz, H.H. Optimizing Production of Tannase and in vitro Evaluation on Ruminal Fermentation, Degradability and Gas Production. International Journal of Dairy Science 2019, 14, 53-60. https://doi.org/10.3923/ijds.2019.53.60.

28. Puri, M.; Banerjee, A.; Banerjee, U.C. Optimization of process parameters for the production of naringinase by Aspergillus niger MTCC 1344. Process Biochem 2005, 40, 195-201, https://doi.org/10.1016/j.procbio.2003.12.009.

29. Puri, M.; Kalra, S. Purification and characterization of naringinase from a newly isolated strain of Aspergillus niger 1344 for the transformation of flavonoids. World Journal of Microbiology \& Biotechnology 2005, 21, 753-758, https://doi.org/10.1007/s11274-004-5488-7.

30. Pegu, B.K.; Chutia, J.; Kardong, D.; Gogoi, D. Optimization of environmental parameters for enhancement of naringinase production of Bacillus cereus-K1 a bacterial strain. Int. J. Adv. Sci. Res. Manag 2019, 4, 6873.

31. Costa da A.M.; Kadowaki, M.K.; Minozzzo, M.C.; de souza, C.G.M.; Boer, C.G.; Brcht, A.; Marina, R. Production, purification and characterization of tannase from Aspergillus tamarii. African Journal of Biotechnology 2012, 11, 391-398.

32. Davis, W.B. Determination of flavanones in citrus industry. Anal. Chem. 1947, 19, 476-478, https://doi.org/10.1021/ac60007a016

33. Mondal, K.C.; Banerjee, D.; Jana, M.; Pati, B.R. Colorimetric assay for determination of tannin acyl hydrolase (E.C. 3.1.1.20) activity. Anal. Biochem 2001, 295, 168-171, https://doi.org/10.1006/abio.2001.5185.

34. Elnashar, M.M. Review article: immobilized molecules using biomaterials and nanobiotechnology. J Biomater Nanobiotechnol 2010, 1, 61-76, https://doi.org/10.4236/jbnb.2010.11008.

35. Srivastava, A.; Kar, R. Application of immobilized tannase from Aspergillus niger for the removal of tannin from myrobalan juice. Indian J. Microbiol 2010, 50, 41-56, https://doi.org/10.1007/s12088-010-0029-6.

36. Rangana, S. Analysis and quality control for fruit and vegetable products. Tata McGraw Hill Education Pvt. Ltd., New Delhi. 2010.

37. Sawhney, S. K. ; Singh, R. Estimation of ascorbic acid in lemon juice, Introductory practical Biochemistry. Narosa Publishing House, New Delhi. 2015; pp.104-105.

38. Kohli, D.; Kumar, A.;Kumar, S.; Upadhyay, S. Waste Utilization of Amla Pomace and Germinated Finger Millets for Value Addition of Biscuits. Current Research in Nutrition and Food Science 2019, 7, 272-279, https://doi.org/10.12944/CRNFSJ.7.1.27.

39. Makkar, H.P.S.; Bluemmel, M.; Borowy, N.K.; Becker, K. Gravimetric determination of tannins and their correlations with chemical and protein precipitation methods. Journal of Science Food Agriculture 1993, 61, $161-165$.

40. Hagerman, A.E.; Butler, L.G. Protein precipitation method for the quantitative determination of tannins. J. Agric. Food Chem 1978, 26, 809-812, https://doi.org/10.1021/jf60218a027.

41. 41. Kumar, S.; Khadka, M.; Mishra, R.; Kohli, D.; Upadhaya, S. Effects of Conventional and Microwave Heating Pasteurization on Physiochemical Properties of Pomelo (Citrus maxima) Juice. J Food Process Technol 2017, 8 .

42. Cornell, J.A. Experiments with mixtures: Designs, models, and the analysis of mixture data. 3rd ed., Wiley Series, In: Probability And Statistics. 2011; https://doi.org/10.1002/9781118204221.

43. Suri, S.; Dutta, A.; Shahi, N.C.; Raghuvanshi, R.S.; Singh, A.; Chopra, C.S. Numerical optimization of process parameters of ready-to-eat (RTE) iron rich extruded snacks for anemic population. LWT - Food Science and Technology 2020, 134, https://doi.org/10.1016/j.lwt.2020.110164. 
44. Massimiliano, R.; Augusta, C.; Rossana, B.; Gerardo, P.; Davide, B.; Roberto, M. The effect of fruit processing and enzymatic treatments on pomegranate juice composition, antioxidant activity and polyphenols content. LWT - Food Science and Technology 2013, 53, 355-359, https://doi.org/10.1016/j.lwt.2013.02.015.

45. Ashima, K.; Hina, I. Efficiency of Tannase Produced by Trichoderma Harzianum MTCC 10841 in Pomegranate Juice Clarification and Natural Tannin Degradation. International Journal of Biotechnology and Bioengineering Research 2006, 4, 641-650.

46. Prakash, S.; Singhal, R.S.; Kulkarni, P.R. Enzymatic debittering of Indian grapefruit (Citrus paradise) juice. Journal of the Science of Food and Agriculture 2002, 82, 394-397, https://doi.org/10.1002/jsfa.1059.

47. Ghosh, U.; Gangopadhyay, H. Enzymatic, physicochemical and rheological behaviour of bael fruit pulp and juice. Indian Journal of Chemicl Technology 2002, 9, 123-126.

48. Patil, M.B.; Dhake, A.B. Debittering of citrus fruit juice by naringinase of Penicillium purpurogenum. Int. J. Engg. Res. \& Sci. \& Tech 2014, 3, 266-270.

49. Singla, G.; Panesar, P.S.; Sangwan, R.S.; Krishania, M. Enzymatic processing of Citrus reticulata (Kinnow) pomace using naringinase and its valorization through preparation of nutritionally enriched pasta. J Food Sci Technol 2020, https://doi.org/10.1007/s13197-020-04846-z.

50. Lima, J.S.; Cruz, R.; Fonseca, J.C.; Medeiros, E.V.; Maciel, M.H.C.; Moreira, K.A.; Motta, C.M.S. Production, characterization of tannase from Penicillium montanense URM 6286 under ssf using agroindustrial wastes, and application in the clarification of grape juice (Vitis vinifera L.). Sci. World J 2014, 2014, 1-9, http://dx.doi.org/10.1155/2014/182025.

51. da Silva, V.M.A.; Cruz, R.; Fonseca, J.C.; de Souza-Motta, C.M.; de Sena, A.R.; Moreira, K.A. Juice clarification with tannases from Aspergillus carneus URM5577 produced by solid-state fermentation using Terminalia catappa L. leaves. African Journal of Biotechnology 2017, 16, 1131-1141, https://doi.org/10.5897/AJB2017.15958.

52. Abdullah, S.; Pradhan, R.C.; Aflah, M.; Mishra, S. Efficiency of tannase enzyme for degradation of tannin from cashew apple juice: Modeling and optimization of process using artificial neural network and response surface methodology. J Food Process Eng 2020, 10, https://doi.org/10.1111/jfpe.13499.

53. Escarpa, A.; González, M.C. Approach to the content of total extractable phenolic compounds from different food samples by comparison of chromatographic and spectrophotometric methods. Analytica Chimica Acta 2001, 427, 119-127, https://doi.org/10.1016/S0003-2670(00)01188-0.

54. Singleton, V.L.; Rossi, J.A. Colorimetric of total phenolics with phosphomolybdic-phosphotungstic acid reagent. American Journal of Enology and Viticulture 1965, 16, 144-158.

55. Cavia-Saiz, M.; Muñiz, P.; Ortega, N.; Busto, M.D. Effect of enzymatic debittering on antioxidant capacity and protective role against oxidative stress of grapefruit juice in comparison with adsorption on exchange resin. Journal Food Chemistry 2011, 125, 158-163, https://doi.org/10.1016/j.foodchem.2010.08.054

56. Sawinder, K.; Sarkar, B.C.; Sharma, H.K.; Charanjiv, S. Response Surface Optimization of Conditions for the Clarification of Guava fruit Juice Using Commercial Enzyme. Journal of Food Process Engineering 2011, 34, 1298-1318, https://doi.org/10.1111/j.1745-4530.2009.00414.x.

57. Essodolom, P.; Chantal, B.E.; Mamatchi, M.; Kous'anta, A. Effect of temperature on the degradation of ascorbic acid (vitamin c) contained in infant supplement flours during the preparation of porridges. International Journal of Advanced research 2020, 8, 116-121, http://dx.doi.org/10.21474/IJAR01/10605. 